\title{
Rancang Bangun Mesin Penebar Pakan Ikan Berbasis Programmable Logic Controller
}

\section{Design Of Fish Feed Spreader Machine Based on Programmable Logic Controller}

\author{
A. Sukma Ardiyan, Diky F., Fany Juvrianto, Winarto dan Ridwan Baharta \\ Jurusan Teknologi Pertanian, Politeknik Negeri Lampung \\ Jl. Soekarno-Hatta, Rajabasa, Bandar Lampung 35144 Tel. (0721)703995
}

\begin{abstract}
The fish feed spreader machine is a feeding tool that is made to facilitate fish breeders in feeding fish. The fish feed spreader is specially programmed to provide fish feed according to the schedule and the desired dose. The purpose of making this tool is to design a fish feed spreader machine based on the logic controller programmale, and to test the performance of the designed fish feed spreader machine. The results showed that the average feed expenditure was $2.66 \mathrm{~kg}$ for a duration of 40 seconds. Then for the farthest throw of feed is 7.5 meters, while for throw of feed that is evenly distributed it has a distance of 5 meters with a spread width of 5.85 meters, and the angle of spread of feed is $90^{\circ}$.
\end{abstract}

Keywords: automatic, fish feed spreader, programmable logic controller

Naskah ini diterima pada tanggal 8 Juni 2020, direvisi pada tanggal 22 Juni 2020 dan disetujui untuk diterbitkan pada tanggal 15 Agustus 2020

\section{PENDAHULUAN}

Dalam bidang peternakan khususnya dalam budidaya perikanan, pemberian pakan sangat dibutuhkan untuk pertumbuhan ikan. Pertumbuhan ikan dalam faktor eksternal selain dipengaruhi oleh suhu dan lingkungan, pemberian pakan sangat berpengaruh dalam pertumbuhan ikan tersebut. Pemberian pakan ikan yang teratur dengan dosis yang sesuai populasi dan umur akan membuat pertumbuhan ikan baik dan sehat, namun jika sabaliknya pemberian pakan ikan tidak sesuai maka ikan akan mengalami pertumbuhan yang tidak rata. Pemberian pakan ikan yang ideal biasanya dilakukan 2-3 kali sehari, pemberian pakan ikan dilakukan pada pagi, siang dan malam hari. Pada proses pemberian pakan berlebih akan menghasilkan sisa pakan yang tersisa di kolam ikan dan hal ini menyebabkan tidak hanya biaya tambahan, tetapi juga kualitas air yang buruk (Ayub et al., 2015).

Pemberian pakan ikan pada umumnya dilakukan secara manual menggunakan tangan. Dengan cara ini jumlah makanan ikan yang diberikan dapat dikontrol, dan dapat langsung dihentikan apabila $25 \%$ dari jumlah ikan yang ada telah meninggalkan tempat pemberian makanan. Dengan demikian pemborosan makanan dapat dihindari, akan tetapi dosis pemberian sering sekali tidak sesuai dengan populasi ikan yang berada di kolam tersebut. Selain itu juga 82 Volume 12, Nomor 2| Agustus 2020: 65-126 
pemberian pakan secara manual lebih banyak menyita waktu peternak dan pemberiannya tidak sesuai dengan jadwal yang telah ditentukan (Afrianto, 1998).

Sedangkan pemberian pakan ikan secara semi mekanik dilakukan dengan cara pakan buatan dimasukkan ke dalam suatu wadah berbentuk bulat yang diletakkan di atas kolam. Wadah ini dilengkapi dengan sebuah klep otomatis yang dapat dibuka setiap kali oleh ikan dengan menggerakkan batu yang dihubungkan dengan benang ke klep tersebut. Ikan yang lapar, secara naluri akan menggerakan batu tersebut dan klep tempat makanan akan terbuka dan makanan pun akan keluar. Pemberian pakan ikan secara semi mekanik juga sejatinya belum memberikan kepuasan kepada pertenak ikan, dikarenakan pemberian pakan ikan dengan cara ini hanya mengandalkan naluri dari ikan, sehingga cara ini akan lebih memperlambat pertmbuhan ikan (Afrianto, 1998). Pemberian pakan ikan otomatis mampu menebar pakan ikan dengan jumlah yang terukur sehingga mampu meningkatkan efisiensi dan mampu mengembangkan budidaya ikan sesuai dengan target (Ariyanto et al., 20014). Penelitian ini bertujuan untuk merancang dan membuat mesin penebar pakan ikan berbasis programmble logic controller serta menguji kinerjanya.

\section{METODE PENELITIAN}

\section{Waktu dan Tempat}

Pembuatan rancang bangun mesin penebar pakan ikan berbasis programmble logic controller akan dilaksanakan tanggal 7 Oktober 2019 hingga 25 November 2019 di Laboratorium Mekanisasi Pertanian Politeknik Negeri Lampung.

\section{Alat dan Bahan}

Adapun alat yang digunakan dalam pembuatan rancang bangun mesin penebar pakan ikan berbasis programmble logic controller dapat dilihat pada Tabel 1.

Tabel 1. Alat Yang Digunakan

\begin{tabular}{clc}
\hline No & \multicolumn{1}{c}{ Alat } & Jumlah Alat \\
\hline 1 & Mesin Las & 1 Unit \\
2 & Gerinda & 1 Buah \\
3 & Mesin Bor & 1 Buah \\
4 & Elektroda & Secukupnya \\
5 & Kunci Pas & 1 Set \\
6 & Multitester & 1 Buah \\
7 & Obeng + & 1 Buah \\
8 & Obeng - & 1 Buah \\
9 & Paku Ripet & Secukupnya \\
10 & Tang Potong & 1 Buah \\
11 & Tang Kombinasi & 1 Buah \\
12 & Cutter & 1 Buah \\
13 & Gergaji Besi & 1 Buah \\
14 & Tang Ripet & 1 Buah \\
15 & Dan Peralatan Lainnya & \\
\hline
\end{tabular}


Adapun bahan yang digunakan dalam pembuatan rancang bangun mesin penebar pakan ikan otomatis berbasis programmble logic controller dapat dilihat pada Tabel 2.

Tabel 2. Bahan Yang Digunakan

\begin{tabular}{clc}
\hline No & \multicolumn{1}{c}{ Bahan } & Jumlah Bahan \\
\hline 1 & Progremmable logic controller (PLC) & 1 Set \\
\hline 2 & Besi Siku & 6 Meter \\
\hline 3 & Termis 1 Fase & 1 Buah \\
\hline 4 & Relay & 2 Buah \\
\hline 5 & Kabel & Secukupnya \\
\hline 6 & Plat Besi & Secukupnya \\
\hline 7 & Solenoid & 1 Buah \\
\hline 8 & Mur dan Baut Ukuran $8 \mathrm{~mm}$ & Secukupnya \\
\hline 9 & Solet Relay & 2 Buah \\
\hline 10 & Motor Pelontar Pakan & 1 Buah \\
\hline 11 & Kotak Panel & 1 Buah \\
\hline 12 & Drum Plastik & 1 Buah \\
\hline 13 & Lampu Indikator & 3 Buah \\
\hline 14 & Push Buttom & 1 Buah \\
\hline 15 & Tombol Emergency & 1 Buah \\
\hline
\end{tabular}

\section{Prosedur Kerja}

Adapun prosedur kerja dari pembuatan rancang bangun mesin penebar pakan ikan otomatis berbasis programmable logic controller ini dapat dilihat pada diagram alir atau flowchart yang di sajikan pada Gambar 1 .

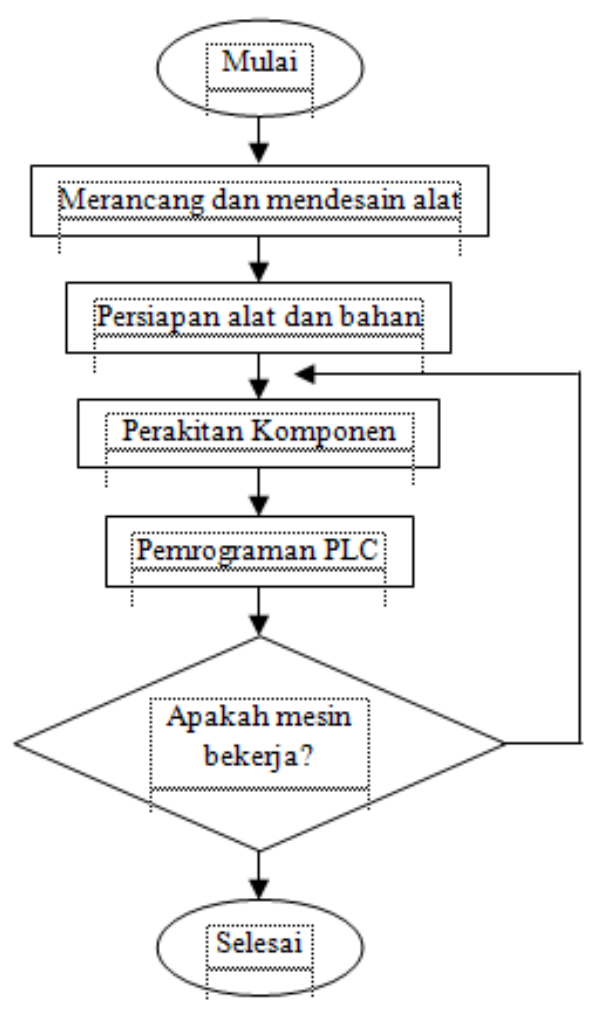

Gambar 1. Diagram alir prosedur kerja 


\section{Rancangan Mesin Penebar Pakan Ikan}

Rancangan mesin penebar pakan ikan otomatis berbasis programmable logic controller terdiri dari dua macam rancangan, rancangan struktural dan rancangan fungsional. Adapun gambar rancangan alat keseluruhan dapat dilihat pada Gambar 2.

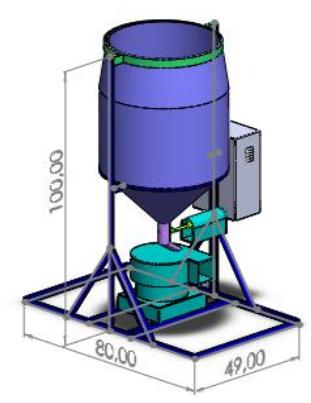

Gambar 2. Mesin penebar pakan ikan

a. Rancangan Struktural

Adapun rancangan struktural dari rancang bangun mesin penebar pakan ikan otomatis berbasis programmable logic controller sebagai berikut.

1. Kerangka

Kerangka alat merupakan komponen yang mengeliling hooper selain itu kerangka juga merupakan bagian yang menopang hooper. Kerangka yang kami gunakan menggunakan bahan besi siku dengan ukuran $3 \times 3$ dan ketebalan $2.8 \mathrm{~mm}$. Ukuran kerangka ini sendiri memiliki panjang $80 \mathrm{~cm}$, lebar $49 \mathrm{~cm}$, dan tinggi $100 \mathrm{~cm}$. Berikut adalah gambar kerangka penebar pakan dapat dilihat pada Gambar 3.

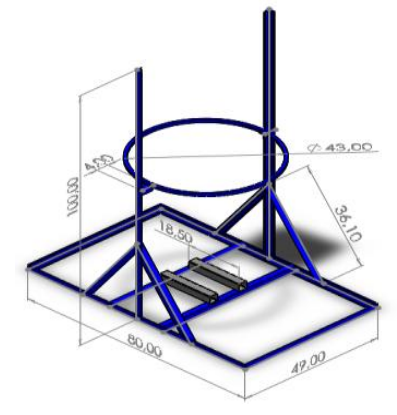

Gambar 3. Kerangka

\section{Hooper}

Hooper merupakan komponen yang digunakan untuk memasukkan atau menyimpan pakan ikan berupa pelet. Hooper yang digunakan padan mesin penebar pakan ini menggunakan drum plastik dengan diameter atas $38 \mathrm{~cm}$ dan tengah $43 \mathrm{~cm}$. Pada bagian bawah drum akan dipotong sepanjang bagian bawah yang berdiameter $43 \mathrm{~cm}$ dan bagian ujung hopper sebagai penyambung pipa penyalur memiliki diameter $4 \mathrm{~cm}$. Pemotongan ini bertujuan untuk menyambung hooper bagian bawah yang berbentuk sudut seperti corong agar pakan ikan dapat menuju bagian penebar dari mesin ini sehingga panjang 
total hooper adalah $66 \mathrm{~cm}$. Sudut kemiring pada hooper belum ditentukan karena sudut pelontaran pakan belum diketahui. Berikut adalah gambar hooper penebar pakan ikan dapat dilihat pada Gambar 4 .

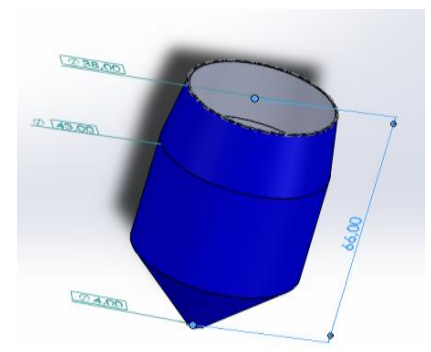

Gambar 4. Hooper

\section{Spinner atau Kipas Pelontar}

Spinner atau kipas pelontar merupakan komponen yang berbentuk seperti kipas pemutar. Bahan yang digunakan untuk spinner adalah plat besi dengan tebal plat 0,4 mm. Pada spinner ini memiliki baling-baling 6 buah, masing-masing baling-baling spinner memiliki ukuran Panjang $9 \mathrm{~cm}$ dengan diameter titik pusatnya $2 \mathrm{~cm}$, sehingga diameter total pada spinner adalah $20 \mathrm{~cm}$. Berikut adalah gambar spinner penebar pakan ikan dapat dilihat pada Gambar 5.

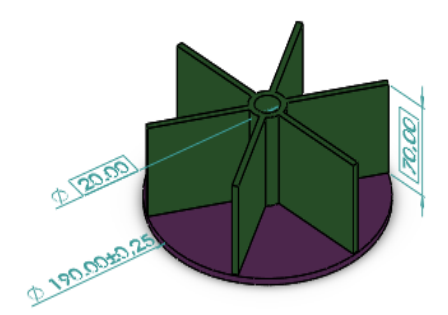

Gambar 5. Spinner atau Kipas Pelontar

\section{Motor Pelontar Pakan}

Motor pelontar pakan yang digunakan pada mesin penebar pakan ikan otomatis berbasis programmable logic controller adalah motor mesin cuci. Motor pelontar pakan ini memiliki spesifikasi $1450 \mathrm{rpm}$. Berikut adalah gambar Motor pelontar pakan penebar pakan ikan dapat dilihat pada Gambar 6.

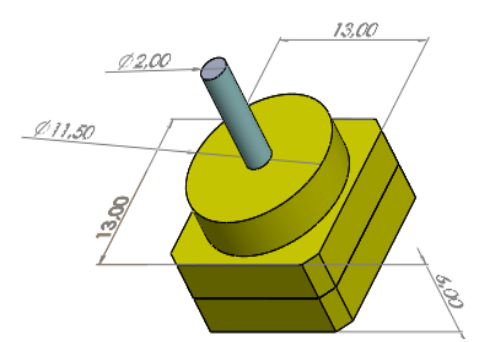

Gambar 6. Motor Pelontar Pakan 
5. Cover Motor pelontar Pakan

Cover Motor Pelontar Pakan merupakan bagian kompenen dari penebar pakan ikan otomatis ini terbuat dari plat besi dengan lebar 19,72 cm, panjang 22,72 cm, dan tinggi $5,5 \mathrm{~cm}$. Dan pada bagian atas terdapat lubang dengan diameter $17 \mathrm{~cm}$. Berikut adalah gambar cover motor pelontar pakan penebar pakan ikan dapat dilihat pada Gambar 7.

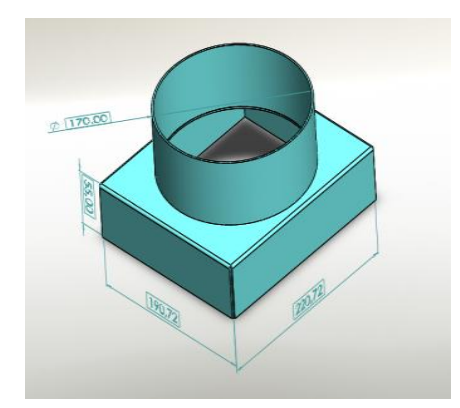

Gambar 7. Cover Motor Pelontar Pakan

\section{Solenoid}

Solenoid merupakan bagian komponen penebar pakan ikan otomatis, solenoid yang digunakan pada alat ini adalah solenoid aktuator motor yang terdapat pada pintu mobil. Spesifikasi solenoid ini sendiri memiliki tengangan $12 \mathrm{~V}$ dengan arus DC. Berikut adalah gambar solenoid penebar pakan ikan dapat dilihat pada Gambar 8.

\section{Cover Solenoid}

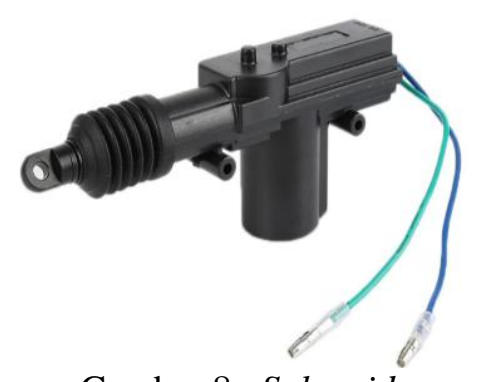

Cover solenoid merupakan bagian yang menutupi solenoid, terbuat dari bhan plat besi yang memiliki ukuran panjang $15 \mathrm{~cm}$, tinggi $5,5 \mathrm{~cm}$, dan lebar $6 \mathrm{~cm}$. Berikut adalah gambar cover solenoid penebar pakan ikan dapat dilihat pada Gambar 9.

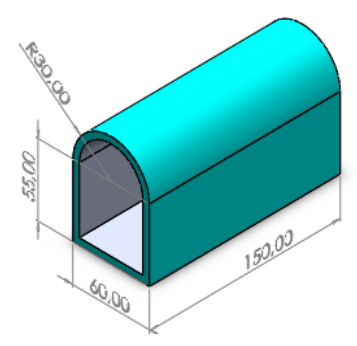

Gambar 9. Cover Solenoid 


\section{Katup Pembuka}

Katub bukaan merupakan bagian komponen penebar pakan ikan otomatis, terbuat dari plat besi yang memiliki ukuran panjang total $3 \mathrm{~cm}$, dan diameter bukaan $2 \mathrm{~cm}$. Berikut adalah gambar katub pembuka penebar pakan ikan dapat dilihat pada Gambar 10.

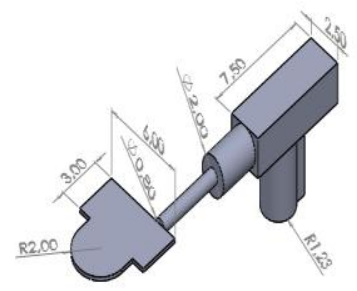

Gambar 10. Katub Pembuka

\section{Pipa Penyalur}

Pipa penyalur merupakan komponen bagian penebar pakan ikan, terbuat dari bahan pipa stainless berdiameter $4 \mathrm{~cm}$. Pipa ini memiliki ukuran tinggi $7,75 \mathrm{~cm}$ dengan sudut menuju spinner $130^{\circ}$. Berikut adalah gambar pipa penyalur penebar pakan ikan dapat dilihat pada Gambar 11.

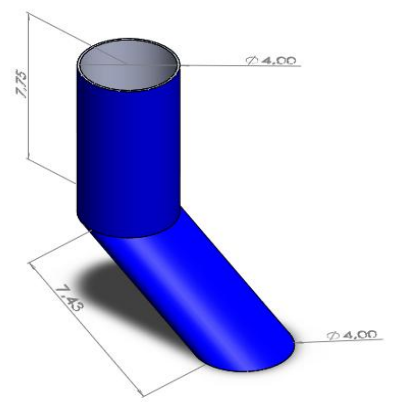

10. Panel Box

Gambar 11. Pipa Penyalur

Panel box merupakan bagian komponen penebar pakan ikan, terbuat dari bahan besi memiliki ukuran panjang $30 \mathrm{~cm}$, lebar $20 \mathrm{~cm}$, dan tinggi $12 \mathrm{~cm}$. Berikut adalah gambar panel box penebar pakan ikan dapat dilihat pada Gambar 12.

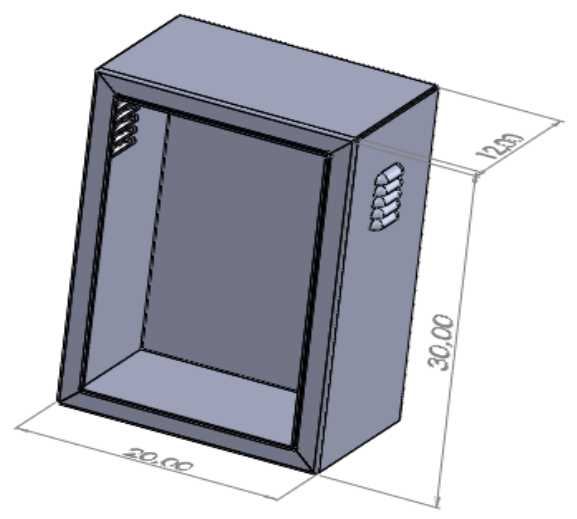

Gambar 12. Panel Box 
b. Rancangan Fungsional

Adapun rancangan fungsional dari rancang bangun mesin penebar pakan ikan otomatis berbasis programmable logic controller sebagai berikut.

1. Kerangka

Kerangka berfungsi sebagai komponen penopang atau penyanggah dari komponenkomponen lainnya, seperti hooper, spinner, Motor pelontar pakan, solenoid, kipas pelontar, cover motor pelontar pakan, cover solenoid, panel box, dan pipa penyalur. Selain itu juga kerangka berfungsi sebagai pondasi bagi komponen-komponen pada mesin penebar pakan ikan (Gambar 3).

\section{Hooper}

Hooper berfungsi sebagai wadah atau penampungan pakan ikan dengan kapasitas pakan ikan yang banyak. Hooper memiliki banyak jenis, tetapi pada mesin penebar pakan ikan kami menggunakan drum plastik (Gambar 4).

3. Spinner atau Kipas Pelontar

Spinner atau Kipas Pelontar berfungsi sebagai pelontar pakan ikan yang digerakan oleh motor pelontar pakan. Spinner ini diharapkan dapat melontarkan pakan ikan secara dengan jarak yang cukup jauh dibandingkan menggunakan penebar pakan lain (Gambar $5)$.

4. Motor Pelontar Pakan

Motor Pelontar Pakan berfungsi sebagai penggerak spinner dengan rpm 1450, motor pelontar pakanakan bergerak sesuai dengan perintah yang telah di program pada programmable logic controller (Gambar 6).

5. Cover Motor Pelontar Pakan

Cover motor pelontar pakan berfungsi sebagai pelindung motor pelontar pakan itu sendiri dari air, karena pada, motor pelontar pakan ini sendiri memiliki arus listrik jika terkena air sangat berbahaya. Sehingga diberi cover sebagai bentuk dari K3 (Gambar 7).

6. Solenoid

Solenoid berfungsi sebagai penarik katub pembuka, dimana saat program berjalan katub pembuka akan membuka melalui tarikan dari solenoid itu sendiri yang bertujuan untuk membuka pengeluar pakan (Gambar 8).

7. Cover solenoid

Cover solenoid berfungsi sebagai pelindung solenoid dari air hujan, tidak jauh beda dengan cover motor pelontar pakan. Solenoid ini juga mengantarkan arus listrik, untuk itu diberi cover supaya terhindar dari konsleting listrik. Pemberian cover juga bagian dari bentuk K3 (Gambar 9). 
8. Katub Pembuka

Katub pembuka berfungsi sebagai pembuka untuk pengeluaran pakan, katub pembuka ini ditarik oleh sloneoid yang sudah diprogram waktu bukaannya (Gambar 10).

9. Pipa Penyalur

Pipa penyalur berfungsi sebagai penyalur pengeluran pakan dari hopper menuju spinner yang kemudia dilontarkan menuju ouput (Gambar 11).

10. Panel Box

Panel box berfungsi sebagai tempat dari rangkaian-rangkaian listrik yang disusun rapi dalam panel box tersebut (Gambar 12).

c. Prosedur Perakitan

Adapun Prosedur Perakitan dari pembuatan rancang bangun mesin penebar pakan ikan otomatis berbasis programmable logic controller sebagai berikut.

1. Menyiapkan alat dan bahan.

2. Memasang motor pelontar pakan pada kerangkan yang sudah disiapkan yang kemudian dikencangkan dengan baut 12.

3. Memasang cover motor pelontar pakanyang bertujuan menutupi motor pelontar pakan.

4. Memasang spinner pada bagian as motor pelontar pakan, yang kemudian dipasang cover spinner sekaligus ouput pengeluaran pakan.

5. Memasang hopper kemudian dekencangkan dengan besi strip yang sudah dibentuk sedemikian rupa sesuai denga diameter hopper.

6. Memasang solenoid pada bagian samping yang sudah dipasang sekaligus cover solenoid.

7. Memasang katub pembuka yang dihubungkan dengan solenoid.

8. Memprogram programmable logic controller untuk menentukan pemberian jadwal pakan ikan yang telah ditentukan.

\section{Pengujian dan Evaluasi}

Pengujian dan evaluasi dilakukan untuk mengetahui sejauh mana kemampuan mesin penebar pakan ikan berbasis programmable logic controller. Pengukuran yang dilakukan berkaitan dengan jadwal dan dosis pemberian pakan ikan sesuai dengan luasan kolam,waktu, dan populasi ikan yang ada pada kolam.

Adapun prosedur pengujian dan evaluasi rancang bangun mesin penebar pakan ikan berbasis programmable logic controller sebagai berikut:

1. Menyiapkan bahan yang akan digunakan.

2. Menimbang bahan atau pelet yang akan disebar pada kolam ikan.

3. Memasukan bahan atau pelet kedalam hopper.

4. Nyalakan mesin penebar pakan ikan pada aliran listrik.

90 Volume 12, Nomor 2| Agustus 2020: 65-126 
5. Menimbang berat hasil penebaran dari pelontaran spinner dengan waktu yang telah ditentukan.

6. Lakukan pengukuran jarak lontar pakan ikan.

Jika hasil penebaran pakan tidak sesuai dengan kebutuhan pakan ikan, lakukan reset pengaturan waktu pada programmable logic controller.

\section{HASIL DAN PEMBAHASAN}

\section{Hasil Pembuatan Alat}

Rancang bangun mesin penebar pakan ikan berbasis programmable logic contorller telah berhasil dibuat dan dapat dilihat pada Gambar 13, 14, dan spesifikasi mesin penebar pakan ikan dapat dilihat pada tabel 3.

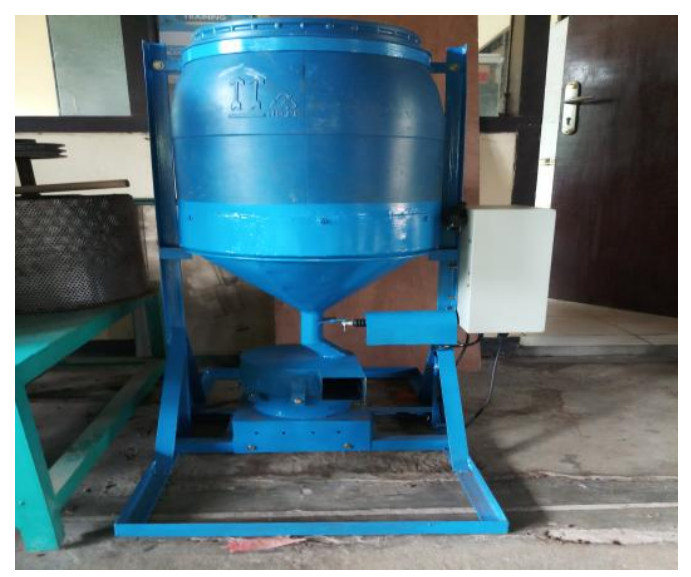

Gambar 13. Tampak Depan

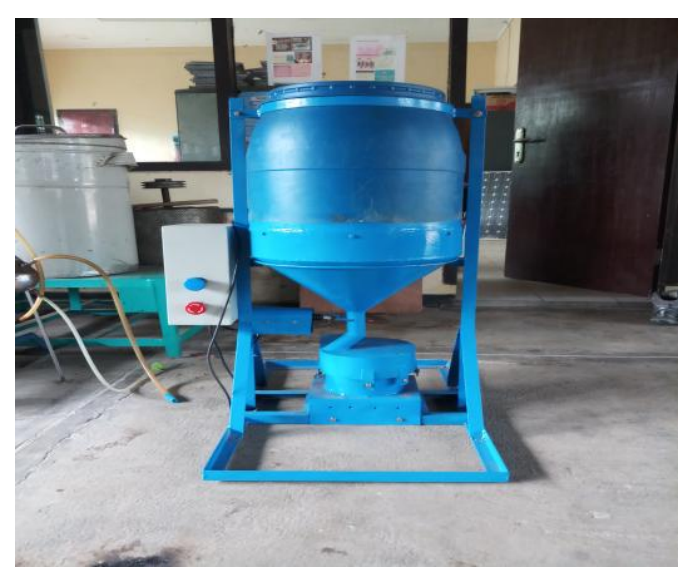

Gambar 14. Tampak Belakang

Tabel 3. Spesifikasi Mesin Penebar Pakan Ikan

\begin{tabular}{clll}
\hline No & \multicolumn{1}{c}{ Komponen Alat } & \multicolumn{1}{c}{ Spesifikasi } \\
\hline 1 & Panjang & $80 \mathrm{~cm}$ & \\
2 & Lebar & $60 \mathrm{~cm}$ & \\
3 & Tinggi & $100 \mathrm{~cm}$ & \\
4 & Hopper & Kapasitas $=18 \mathrm{~kg}$ & $\varnothing$ Atas $=32 \mathrm{~cm}$ \\
& & Tinggi $=84 \mathrm{~cm}$ & $\varnothing$ Bawah $=42,6 \mathrm{~cm}$ \\
5 & Spinner & $\emptyset 20 \mathrm{~cm}$ & \\
6 & Motor Pelontar Pakan & $180 \mathrm{Watt}$ & \\
7 & Solenoid & $12 \mathrm{~V} / 24 \mathrm{~V}$ & \\
8 & Katub Pembuka & Panjang $=6 \mathrm{~cm}$ & $\emptyset=4 \mathrm{~cm}$ \\
9 & Jarak Lontar & $7,5 \mathrm{~meter}$ & \\
10 & Sudut Pelontaran & $90^{\circ}$ & \\
11 & Keluaran Pakan Perdetik & 0,62 gram & \\
\hline
\end{tabular}

Dalam proses pembuatan rancang bangun mesin penebar pakan ikan berbasis programmable logic controller harus dilakukan secara teliti dan sesuai ukuran yang telah ditentukan atau didesain sembelum pembuatan alat. Bahan-bahan yang dibutuhkan didapat dari toko besi, toko drum, dan elektronika yang berada diwilayah Bandar Lampung dan sekitarnya. 
Tahapan pertama dari rancang bangun alat ini adalah pembuatan kerangka yang bertujuan sebagai penyanggah atau penopang komponen-komponen lainnya. Kemudian pembuatan corong dan drum sebagai hopper yang menapung pakan ikan yang akan disebar. Selanjutnya adalah pembuatan kipas pelontar atau spinner dan cover spinner sekaligus ouput pengeluaran pakan. Tahap berikutnya adalah perakitan komponen elektronika

\section{Kalibrasi Jumlah Keluaran Pakan Ikan Berdasarkan Pewaktu}

Dalam menentukan jumlah pengeluaran pakan ikan dalam luasan kolam yang besar, tentunya dibutuhkan data yang akurat agar pemberian pakan sesuai dengan jadwal dan dosis yang diinginkan. Data hasil kalibrasi pewaktu dan pengeluaran pakan dapat dilihat pada tabel 4.

Tabel 4. Hasil Kalibrasi Alat

\begin{tabular}{|c|c|c|c|}
\hline Percobaan & $\begin{array}{l}\text { Waktu } \\
\text { (detik) }\end{array}$ & $\begin{array}{c}\text { Berat pakan keluar } \\
(\mathrm{kg})\end{array}$ & Rata-rata (kg) \\
\hline \multirow[t]{3}{*}{1} & 30 detik & 1,85 & 1,86 \\
\hline & & 1,9 & \\
\hline & & 1,85 & \\
\hline \multirow[t]{3}{*}{2} & 40 detik & 2,55 & 2,6 \\
\hline & & 2,75 & \\
\hline & & 2,5 & \\
\hline \multirow[t]{3}{*}{3} & 45 detik & 2,85 & 2,81 \\
\hline & & 2,8 & \\
\hline & & 2,8 & \\
\hline \multirow[t]{3}{*}{4} & 60 detik & 3,75 & 3,76 \\
\hline & & 3,75 & \\
\hline & & 3,8 & \\
\hline \multirow[t]{3}{*}{5} & 90 detik & 5,85 & 5,83 \\
\hline & & 5,8 & \\
\hline & & 5,8 & \\
\hline
\end{tabular}

Berdasarkan data untuk populasi ikan sebanyak 1500 ekor dimana berat ikannya $100 \mathrm{~g}$ per ekor, dan feeding rationya $5 \%$, maka jumlah pemberian pakan perharinya sebanyak $7,5 \mathrm{~kg}$. Dan bila penebaran pakan dilakukan tiga kali sehari, maka tiap tebarnya diperlukan pakan 2,5 $\mathrm{kg}$. Dari data hasil kalibrasi pewaktu dan pengeluaran pakan pada mesin hasil rancang bangun (Tabel 4), maka pengaturan waktu yang pas pada PLC adalah 40 detik bukaan solenoid.

\section{Hasil Uji Kinerja}

1. Pengeluaran Pakan Ikan

Adapun data pengeluaran pakan ikan saat dilakukan pengujian mesin penebar pakan ikan hasil rancang bangun dengan durasi waktu 40 detik (sesuai seting pewaktu hasil kalibrasi dari Tabel 4) 
Tabel 4. Pengeluaran Pakan Ikan

\begin{tabular}{ccc}
\hline No & Waktu (dt) & Jumlah Pengeluaran (Kg) \\
\hline 1 & 40 Detik & $2,65 \mathrm{~kg}$ \\
\cline { 1 - 2 } 2 & 40 Detik & $2,65 \mathrm{~kg}$ \\
\cline { 3 - 3 } 3 & 40 Detik & $2,7 \mathrm{~kg}$ \\
\hline & Rata-rata & $\mathbf{2 , 6 6 ~ k g}$ \\
\hline
\end{tabular}

Dari hasil uji kinerja mesin di lapangan diperoleh hasil bahwa terdapat kelebihan sebanyak $0,16 \mathrm{~kg}$ dari yang seharusnya 2,5 $\mathrm{kg}$ setiap satu kali penebaran pakan. Jumlah tersebut masih dalam rentang yang bisa ditolerir.

2. Pewaktu PLC dan Stopwatch

Data pewaktu dari setting programmable logic controller untuk menggerakkan solenoid dan motor penebar pakan dibandingkan dengan pewaktuan stop watch. Berdasarkan hasil uji diperoleh hasil seperti tampak pada Tabel 5.

Tabel 5. Pewaktu PLC dan Stopwatch

\begin{tabular}{ccccc}
\hline No & solenoid & $\begin{array}{c}\text { Pewaktu PLC } \\
\text { Motor Pelontar } \\
\text { Pakan }\end{array}$ & Solenoid & $\begin{array}{c}\text { Pewaktu Stopwatch } \\
\text { Motor Pelontar } \\
\text { pakan }\end{array}$ \\
\hline 1 & $40 \mathrm{~s}$ & $60 \mathrm{~s}$ & $40 \mathrm{~s}$ & $59,96 \mathrm{~s}$ \\
\hline 2 & $40 \mathrm{~s}$ & $60 \mathrm{~s}$ & $40,03 \mathrm{~s}$ & $60,01 \mathrm{~s}$ \\
\hline 3 & $40 \mathrm{~s}$ & $60 \mathrm{~s}$ & $40.01 \mathrm{~s}$ & $59,98 \mathrm{~s}$ \\
\hline Rata-rata & $\mathbf{4 0 ~ s}$ & $\mathbf{6 0 ~ s}$ & $\mathbf{4 0 , 0 1 ~ s}$ & $\mathbf{5 9 , 9 8 ~ s}$ \\
\hline
\end{tabular}

Data diatas menujukkan bahwa pewaktu PLC dengan Stopwatch memiliki selisih waktu yang tidak bagitu signifikan, contoh rata-rata pewaktu pada programmable logic controller dengan aplikasi motor pelontar pakan dan solenoid yang memiliki waktu pada motor pelontar pakan60 sekon dan solenoid 40 sekon. Dengan pewaktu pada stopwatch yang memiliki waktu pada motor pelontar pakan 59,94 sekon dan solenoid 40,10 sekon. Pewaktu tersebut menunjukkan perbedaan pewaktu PLC dengan stopwatch dengan pengaplikasian solenoid adalah 0,10 sekon dan perbedaan pewaktu PLC dengan stopwatch dengan pengaplikasian motor pelontar pakan adalah 0,06 sekon.

3. Jarak Pelemparan Pakan

Hasil pengujian pelemparan pakan mesin hasil rancang bangun memberikan hasil seperti tampak pada Tabel 6 untuk putaran motor $1450 \mathrm{rpm}$. Pelemparan terjauh berkisar antara 7,57,6 m, sedangkan pelemparan yang mengelompok berada pada jarak $5 \mathrm{~m}$ dari mesin penebar pakan.

Tabel 6. Jarak Lontaran Pakan

\begin{tabular}{cccccc}
\hline No & RPM & $\begin{array}{c}\text { Panjang } \\
\text { Lontaran }\end{array}$ & $\begin{array}{c}\text { Lebar } \\
\text { Lontaran }\end{array}$ & $\begin{array}{c}\text { Sudut } \\
\text { penebaran }\end{array}$ & $\begin{array}{c}\text { Rata-rata } \\
\text { Lontaran }\end{array}$ \\
\hline 1 & 1450 & $7,5 \mathrm{~m}$ & $5,85 \mathrm{~m}$ & $90^{\circ}$ & $5 \mathrm{~m}$ \\
\hline 2 & 1450 & $7,55 \mathrm{~m}$ & $5,8 \mathrm{~m}$ & $90^{\circ}$ & $5 \mathrm{~m}$ \\
\hline 3 & 1450 & $7,6 \mathrm{~m}$ & $6 \mathrm{~m}$ & $90^{\circ}$ & $5 \mathrm{~m}$ \\
\hline
\end{tabular}


Sedangkan lebar pelemparan berkisar antara 5,8-6 m dengan membentuk sudut lempar/penebaran sebesar $90^{\circ}$.

\section{KESIMPULAN}

Berdasarkan hasil penelitian dapat disimpulkan:

Pengeluaran pakan rata-rata 2,66 kg dengan durasi waktu 40 detik untuk sekali pemberian pakan. Kemudian untuk jarak terjauh lontaran pakan yaitu 7,5 meter, sedangkan untuk lontaran pakan yang sebarannya merata memiliki jarak 5 meter dengan lebar sebar 5,85 meter, dan sudut penebaran pakan $90^{\circ}$.

\section{DAFTAR PUSTAKA}

Afrianto, Eddy. 1998. Beberapa Metode Budidaya Ikan. Hal 40. Kanisius, Yogyakarta.

A. M. Novita., Nurlita Abdulgani. 2013. Pengaruh Pemberian Pakan Alami dan Pakan Buatan Terhadap Pertumbuhan Ikan Betutu (Oxyeleotris Marmorata) Pada Skala Laboratorium. Jurnal Sains dan Seni Pomits, Vol.2 (1) : 2337-3520.

Ariyanto, E.Y., Aman, M. and Rochmad, C.D., 2014. Perancangan dan Pembuatan Sistem Penebar Pakan Ikan Jenis Pasta Otomatis Berbasis Mikrokontroler At89s51. Program Kreativitas Mahasiswa-Karsa Cipta

Ayub, M.A., Kushaini, S. and Amir, A., 2015. A new mobile robotic system for intensive aquaculture industries. Journal of Applied Science and Agriculture, 10(8), pp.1-7.

Ciptanto, Sapto. 2010. Top 10 Ikan Air Tawar (Edisi 1). Hal 54-62. C.V Andi Offset, Yogyakarta.

N, Kholidi, Anwar., Agus Trisanto dan Emir Nasrullah. 2015. Rancang Bangun Alat Pemberi Pakan dan Pengatur Suhu Otomatis Untuk Ayam Pedaging Berbasis Programmable Logic Controller Pada Kandang Tertutup. Jurnal Rekayasa dan Teknologi Elektro, Vol.9 (2) : 87.

Pamungkas, Agus, Eko Didi Krisdianto dan Mahmuda Firdaus. 2014. Rancang Bangun Alat Penebar Pakan Ikan Secara Otomati Dengan Menggunakan Auger dan Blower. Proyek Usaha Mandiri. Politeknik Negeri Lampung, Bandar Lampung. 